\title{
Potential impacts of black carbon on the marine microbial community
}

\author{
Andrea Malits ${ }^{1,2, *}$, Raffaela Cattaneo ${ }^{1,2}$, Eva Sintes ${ }^{3,4}{ }^{\text {, Josep M. Gasol }}{ }^{5}$, \\ Gerhard J. Herndl ${ }^{3,4}$, Markus G. Weinbauer ${ }^{1,2}$ \\ ${ }^{1}$ Sorbonne Universités, UPMC Univ Paris 06, UMR 7093, LOV, Observatoire océanographique, \\ 06230 Villefranche/mer, France \\ ${ }^{2}$ CNRS, UMR 7093, LOV, Observatoire océanographique, 06230 Villefranche/mer, France \\ ${ }^{3}$ Department of Biological Oceanography, Royal Netherlands Institute for Sea Research (NIOZ), PO Box 59, \\ 1790 AB Den Burg, The Netherlands \\ ${ }^{4}$ Department of Limnology and Oceanography, Faculty Center of Ecology, Althanstr. 14, 1090 Vienna, Austria \\ ${ }^{5}$ Institut de Ciències del Mar, CSIC, Departament de Biologia Marina i Oceanografia, Passeig Maritim de la Barceloneta, \\ 37-49, 08003 Barcelona, Catalonia, Spain
}

\begin{abstract}
Black carbon (BC) is the carbonaceous residue of the incomplete combustion of fossil fuels and biomass and encompasses a range of chemically heterogeneous substances from partly charred plant material to highly condensed soot aerosols. We addressed the potential role of $\mathrm{BC}$ aerosol deposition on marine microbial processes in the ocean by investigating the effects of BC reference material (and its exposure to simulated solar radiation) on viral and bacterial activity in batch cultures with aged seawater. Viruses and bacteria were rapidly adsorbed to BC. No difference between the effect of irradiated and non-irradiated $\mathrm{BC}$ on free viral parameters was observed. Bacterial leucine incorporation was higher in the BC treatments than in the BC-free controls. The stimulated bacterial production in the dark BC treatments might be caused by the reduction of viral infection due to adsorption of organic material or by direct use of $\mathrm{BC}$ material. Viral production was significantly lower in BC-amended treatments than in BC-free controls, and the estimated fraction of infected cells decreased with increasing BC concentration. Moreover, bacterial activity in the solar-radiation-exposed BC treatments was higher than in the dark BC treatments, indicating that radiation made BC more accessible to bacteria. Our data reveal that BC has the potential to stimulate bacterial activity in the water column, particularly after exposure to solar radiation. Rising BC levels in the atmosphere due to increasing anthropogenic emissions could have far-reaching effects, including potential stimulation of seawater heterotrophy and $\mathrm{CO}_{2}$ production, through its effects on bacteria and viruses.
\end{abstract}

KEY WORDS: Black carbon aerosols $\cdot$ Light exposure $\cdot$ Viral lysis $\cdot$ Bacterial production

\section{INTRODUCTION}

Black carbon (BC) refers to the carbonaceous products of incomplete combustion of vegetation and fossil fuels, and is defined as a continuum of compounds from partly charred plant material to highly condensed soot aerosols (Goldberg 1985, Schmidt \&
Noack 2000, Mannino \& Harvey 2004). These thermogenic compounds are chemically heterogeneous and are all characterized by high carbon content and aromatic structures, which are particularly resistant to biodegradation (Goldberg 1985, Schmidt \& Noack 2000). BC particles constitute aggregates of small carbon spheres (Cattaneo et al. 2010), whose fractal 
morphology, i.e. their high porosity, offers an important surface area for the adsorption of organic matter (Cornelissen et al. 2005, Koelmans et al. 2006). BC particles occur in a wide size range, and small soot particles $(<1 \mu \mathrm{m})$ easily become airborne and can remain in the atmosphere for weeks and spread over remote areas including the open ocean (Masiello 2004, Hadley et al. 2007). During atmospheric transport, BC aerosols efficiently absorb solar radiation and are the second strongest contributor to current global warming (Ramanathan \& Carmichael 2008).

$\mathrm{BC}$ is introduced into the ocean by atmospheric deposition of land-derived aerosols (Jurado et al. 2008), via river estuarine systems (Mitra et al. 2002, Kim et al. 2004, Elmquist et al. 2008, Stubbins et al. 2010), and by marine diesel engine exhausts (Lack et al. 2008). Dry and wet deposition of BC to the global ocean is estimated to be 2 and $10 \mathrm{Tg} \mathrm{C} \mathrm{yr}^{-1}$, respectively, with higher fluxes over the northern hemisphere (Jurado et al. 2008). A portion of BC becomes soluble over time and enters the dissolved organic matter (DOM) pool (Kim et al. 2004). Dissolved BC has been observed throughout different domains of the ocean accounting for 1 to $9 \%$ of the DOM pool with a strong coastal to open ocean concentration gradient (Mannino \& Harvey 2004, Dittmar \& Koch 2006, Dittmar \& Paeng 2009, Ziolkowski \& Druffel 2010, Dittmar et al. 2012). In open ocean sediments, $\mathrm{BC}$ is up to $14000 \mathrm{yr}$ older than the co-deposited bulk organic carbon, suggesting that the small and light $\mathrm{BC}$ particles are not used but are retained in the dissolved organic carbon (DOC) pool before being deposited in marine sediments (Masiello \& Druffel 1998). However, isotopic analysis revealed the petrogenic origin of $\mathrm{BC}$ in marine sediments and suggested a significant overestimation of combustionderived BC burial in sediments and underestimation of degradation processes in the water column (Dickens et al. 2004). Additionally, the low contribution of $\mathrm{BC}$ to marine DOC in the open ocean, i.e. less than $3.5 \%$ (Dittmar \& Paeng 2009, Ziolkowski \& Druffel 2010), suggests that BC is more labile than formerly believed. Recent studies on the photochemical (Stubbins et al. 2012) and microbial degradation of BC (Zimmerman 2010) indeed challenge the previous assumption on the refractory character of BC.

Despite the ubiquitous presence of $\mathrm{BC}$ in the oceanic particulate organic matter (POM) (FloresCervantes et al. 2009) and DOM pools, its effect on marine systems and its role in the marine carbon cycle remain largely enigmatic. It has been demonstrated that $\mathrm{BC}$ reference material rapidly adsorbs viruses and bacteria (Cattaneo et al. 2010) and stim- ulates the aggregation of organic particles and bacterial production (Mari et al. 2014). Also, there is evidence that $\mathrm{BC}$ can have an influence on viral and bacterial diversity (Cattaneo et al. 2010, Weinbauer et al. 2012).

Viruses are important mortality agents in the ocean, structuring microbial communities and influencing biogeochemical cycles (Fuhrman 1999, Suttle 2007) by converting cells into DOM and increasing the recycling and retention of nutrients in the photic zone (Wilhelm \& Suttle 1999). Organic particles, in turn, may provide shelter to bacteria from viral infection, although experimental results are controversial (Suttle \& Chen 1992, Noble \& Fuhrman 1997, Riemann \& Grossart 2008, Sheik et al. 2014). As BC particles are a relevant type of organic particle, knowledge on the potential impact of BC-rich aerosols on production and viral-mediated loss of microorganisms and the consequences for biogeochemical cycles in the sea is needed.

To explore the potential mechanisms playing a role in the response of prokaryotes and associated viruses to $\mathrm{BC}$, we set up 2 experiments in which we added various concentrations of standard BC to a standardized equilibrated community from aged seawater from the North Sea. Exposure of BC to solar radiation, a phenomenon that commonly occurs during atmospheric transport, was simulated, and its effect on BC bioavailability to bacteria was also investigated.

Our experiments provide insight into the potential effects of BC on the microbial community, such as: (1) a stimulating effect of $\mathrm{BC}$ on bacterial heterotrophic production, as BC is ultimately a carbon source, (2) an increased bioavailability of $\mathrm{BC}$ due to previous solar radiation mimicking atmospheric transport, (3) attachment of bacteria and viruses, as BC are organic particles with a high surface area, and (4) a deleterious effect on viral infectivity due to attachment and loss of activity.

\section{MATERIALS AND METHODS}

\section{Experimental set-up}

Two experiments were performed in May 2005 with aged surface seawater from the open North Sea collected in August 2004 from onboard the RV 'Pelagia' at the North Sea Oyster Grounds (54 $30^{\prime} \mathrm{N}, 04^{\circ}$ $\left.30^{\prime} \mathrm{E}\right)$ and kept in the dark at $20^{\circ} \mathrm{C}$.

Aged seawater was chosen because it is not limited in inorganic nutrients, but instead in organic carbon. 
During aging, more degradable organic matter is eliminated which otherwise would obstruct the use of a more refractory carbon source such as BC. Also, other organic particles present in un-aged seawater might adsorb viruses and bacteria and bias the interaction between $\mathrm{BC}$ particles and viruses or bacteria. Additionally, aged seawater was used to ensure that the microbial community was in a steady state. Steady-state conditions were assessed prior to the experiments by measuring selected bacterial parameters for 3 consecutive days; these parameters were sampled every $13 \pm 3 \mathrm{~h}$ and exhibited variations of $\leq 4 \%$ (data not shown). The rationale of the present study was to explore the potential mechanisms playing a role in the response of the microbial food web to $\mathrm{BC}$ rather than studying the effect of $\mathrm{BC}$ on any specific planktonic community. Therefore we used a standardized equilibrated community.

The first experiment was designed to assess the effect of a defined concentration of BC and consisted of duplicate incubations of seawater with and without receiving $\mathrm{BC}$ (experiment $B C$-fix). In the second experiment, a gradient of $\mathrm{BC}$ concentrations was tested in non-replicated incubations (experiment $B C$ grad). In both experiments, BC reference material (SRM 2975, Diesel Particulate Matter from the US Department of Commerce, National Institute of Standards and Technology [NIST], Gaithersburg, MD) was used. Soot carbon represents $95 \%$ of NIST diesel particulate matter (versus 5\% organic carbon, Gustafsson et al. 1997), and the trace metal content of SRM 2975 is low (0.22 wt.\%, Jensen 2006). The majority of BC reference material particles are within the size range of 1.5 to $4 \mu \mathrm{m}$ equivalent spherical diameter (ESD). Details on the size distribution of SRM 2975 are given by Cattaneo et al. (2010).

Before being employed in the experiments, BC stock solutions (BC added to ultrapure [MilliQ, Millipore] water at concentrations of $20 \mathrm{mg} \mathrm{l}^{-1}$ in experiment $B C$-fix and $100 \mathrm{mg} \mathrm{l}^{-1}$ in experiment $B C$-grad) were either kept in the dark or exposed to artificial solar radiation in quartz tubes $(2.8 \mathrm{~cm}$ inner diameter) for $15 \mathrm{~h}$ and $23 \mathrm{~h}$, in $B C$-fix and $B C$-grad, respectively. Artificial solar radiation was supplied by 3 different types of light sources. Two HQI-T Powerstar (Osram) lamps provided photosynthetically active radiation (400-700 $\mathrm{nm}$ wavelength range), $2 \mathrm{TL}$ 100W/10R fluorescent light tubes (Philips) were used to provide UV-A (320-400 nm), and 3 UVA-340 fluorescent light tubes (Q-Panel) supplied UV-A and UVB (300-320 nm). The solar simulator was adjusted to $30-60 \%$ of the local maximum radiation intensity in late spring measured on a cloudless day (Pausz \&
Herndl 2002). Thus, the dose rate received was similar to that expected in the top surface layer of the North Sea water column. For the dark control (unexposed) treatment, the BC stock was kept in the dark in glass tubes wrapped in aluminum foil in the same incubator. During the exposure to artificial solar radiation, BC stocks were kept in a flow-through water bath connected to a temperature control unit (LAUDA RCS/RC-6).

In experiment $B C$-fix, $10 \mathrm{ml}$ of the light-exposed (BC-light treatment) and unexposed BC stock (BCdark treatment) were added to $1 \mathrm{l}$ of unfiltered aged seawater in duplicate acid-rinsed borosilicate bottles to obtain a final $\mathrm{BC}$ concentration of $200 \mu \mathrm{g} \mathrm{l}^{-1}$. For experiment $B C$-grad, the BC stock solution was added to $1 \mathrm{l}$ of aged seawater to obtain the following concentration gradient: 200, 500, 1000, and $2000 \mu \mathrm{g}$ light-exposed $\mathrm{BC}^{-1}$ (BC-light treatments) and 500 and $2000 \mu \mathrm{g}$ unexposed $\mathrm{BC} \mathrm{l}^{-1}$ (BC-dark treatments). The highest $\mathrm{BC}$ concentration measured to date in coastal seawater is $162 \mathrm{\mu g} \mathrm{l}^{-1}$ (Mannino \& Harvey 2004), i.e. similar to the concentrations added in experiment $B C$-fix $\left(200 \mu \mathrm{g} \mathrm{l}^{-1}\right)$. Experiment $B C$-grad with up to 10-fold higher additions of $B C$ than has been found in marine environments was designed to unveil the basic effects of $\mathrm{BC}$ on microbes, rather than simulating scenarios at ecologically relevant concentrations. Elevated concentrations of BC should also amplify the sorption dynamics and potentiate the interaction between particles and cells or viruses, respectively.

In both experiments, $10 \mathrm{ml}$ of ultrapure water were added to the $\mathrm{BC}$-free controls, and all bottles were incubated in the dark at $20^{\circ} \mathrm{C}$ for $4 \mathrm{~d}$ and sampled every $13 \pm 6 \mathrm{~h}$. We started sampling $\left(\mathrm{t}_{0}\right)$ approximately $10 \mathrm{~min}$ after adding the $\mathrm{BC}$ material. The incubation bottles were thoroughly mixed prior to sampling.

\section{Determination of DOC and inorganic nutrients}

Samples for the measurement of dissolved inorganic nutrient concentrations $\left(\mathrm{NH}_{4}{ }^{+}, \mathrm{NO}_{3}{ }^{-}, \mathrm{NO}_{2}{ }^{-}\right.$, $\mathrm{PO}_{4}{ }^{3-}$ ) were pre-filtered through $0.2 \mu \mathrm{m}$ polycarbonate filters (GTTP, Millipore), and subsequently analyzed in a TRAACS 800 autoanalyzer system. $\mathrm{NH}_{4}{ }^{+}$ was detected with the indo-phenol blue method $(\mathrm{pH}$ 10.5) at $630 \mathrm{~nm}$ (Helder \& De Vries 1979). $\mathrm{NO}_{2}{ }^{-}$, $\mathrm{NO}_{3}{ }^{-}$, and $\mathrm{PO}_{4}{ }^{3-}$ were determined following the Joint Global Ocean Fluxes Study recommendations (Gordon et al. 1993). $\mathrm{NO}_{2}{ }^{-}$was detected after diazotation with sulfanilamide and N-(1-naphtyl)-ethylene 
diammonium-dichloride as the reddish-purple dye complex at $540 \mathrm{~nm} . \mathrm{NO}_{3}{ }^{-}$was reduced in a copper cadmium coil to nitrite and then measured as nitrite. $\mathrm{PO}_{4}{ }^{3-}$ was determined via the molybdenum blue complex at $880 \mathrm{~nm}$.

Samples for DOC measurements were filtered through Whatman GF/F filters using a glass filtration system. The Whatman GF/F filters and all of the glassware were combusted $\left(450^{\circ} \mathrm{C}\right.$ for $\left.4 \mathrm{~h}\right)$ prior to the filtration. Eight $\mathrm{ml}$ of filtered samples were transferred to combusted glass ampoules, and $50 \mu \mathrm{l}$ of $40 \%$ phosphoric acid were added to each sample. Afterwards, the ampoules were sealed and stored at $4^{\circ} \mathrm{C}$ in the dark and analyzed within 1 mo. DOC concentrations were determined in triplicate using a Shimadzu TOC-5000 analyzer (Benner \& Strom 1993).

\section{Determination of total bacterial abundance, respiring bacteria, and 'live' versus 'dead' bacteria}

Water samples for total bacterial abundance $(1.8 \mathrm{ml})$ were fixed with paraformaldehyde $(1 \%)$ and glutaraldehyde $(0.05 \%)$, kept at room temperature for ca. $10 \mathrm{~min}$, and then flash-frozen in liquid nitrogen. Within a few days, the samples were thawed, stained with SYBR Green I (Molecular Probes, Invitrogen) at $10 \times$ dilution for $10 \mathrm{~min}$, amended with Fluoresbrite ${ }^{\circledR}$ Yellow Green (YG) beads of $0.98 \mu \mathrm{m}$ diameter (Polysciences) as an internal standard, and analyzed in a Becton Dickinson FACSCalibur flow cytometer as described previously (Gasol \& del Giorgio 2000).

Bacteria were detected in plots of $90^{\circ}$ light scatter (SSC) and green DNA fluorescence (Fig. 1). Differences in the green fluorescence and SSC signature in the cytometric plot allowed us to separate different bacterial populations according to their nucleic acid content, i.e. low (LNA) and high nucleic acid (HNA) content, as previously described (Gasol et al. 1999).

In the samples with $\mathrm{BC}$ additions, we detected an additional population with a SYBR Green derived fluorescence comparable to HNA bacteria, yet with a much higher SSC (Fig. 1). The bacteria in that gate were operationally considered to be particle-associated bacteria (PAB) assuming that the increase in SSC without parallel increase in nucleic acid-derived fluorescence had to be due to the association of bacteria with particles.

The numbers of actively respiring bacteria were determined by the fluorogenic tetrazolium dye CTC (5-cyano-2,3-ditolyl tetrazolium chloride) labeling of

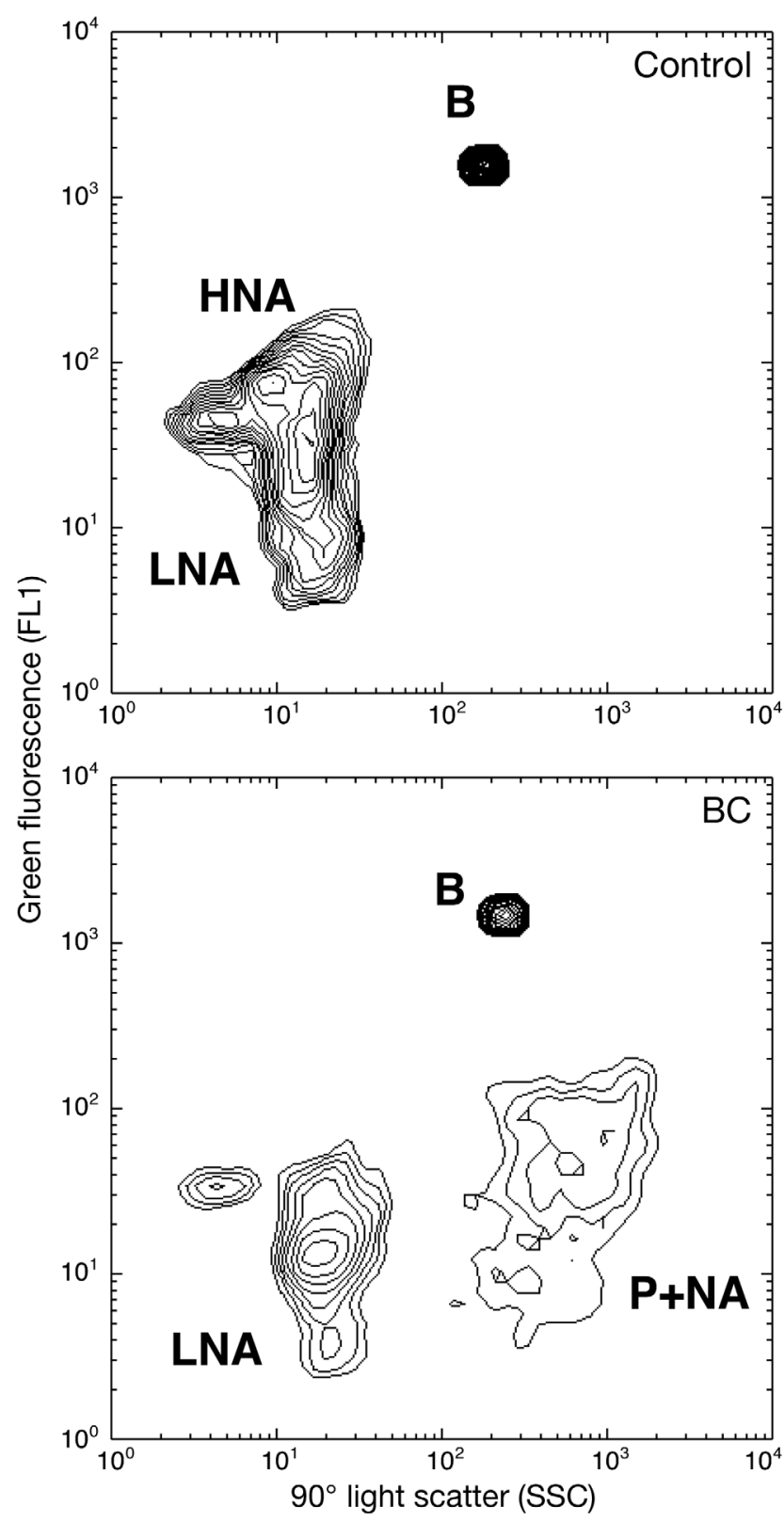

Fig. 1. Flow cytometric plot of side scatter (SSC) versus green florescence (FL1) of SYBR-Green-stained bacteria from experiment $B C$-grad. Examples are given of bacteria that had received black carbon $\left(\mathrm{BC}_{i}\right.$ lower panel) and bacteria from the $\mathrm{BC}$-free control (upper panel). A secondary population of particle-associated bacteria $(\mathrm{P}+\mathrm{NA})$ with higher SSC and similar fluorescence to high nucleic acid (HNA) bacteria is evident in the lower panel. B: beads; LNA: low nucleic acid bacteria

highly active cells (del Giorgio et al. 1997, Sherr et al. 1999, Sieracki et al. 1999). Five mM CTC of a daily prepared batch was added to water samples and incubated at $20^{\circ} \mathrm{C}$ for $3 \mathrm{~h}$. After incubation, the samples were analyzed with a Becton Dickinson FAC- 
SCalibur flow cytometer as described in detail elsewhere (Gasol \& Arístegui 2007).

We also discriminated 'live' or membrane-intact from 'dead' or membrane-damaged bacteria using the nucleic-acid double staining protocol (Gregori et al. 2001) as explained in detail elsewhere (Falcioni et al. 2008). In brief, samples were dually stained with propidium iodine $\left(10 \mu \mathrm{g} \mathrm{ml}^{-1}\right)$, a membrane-impermeable red dye, and SYBR Green I (Molecular Probes, Invitrogen), a membrane-permeable green dye, for 15 min, and then analyzed in a Becton Dickinson FACSCalibur flow cytometer at a low speed (ca. $15 \mu \mathrm{l} \mathrm{min}{ }^{-1}$ ). A dot plot of red (FL3 cytometric channel) versus green fluorescence (FL1 cytometric channel) allowed distinction of the 'live' cells from the 'dead' cells. 'Live' cells were considered those having more green than red staining, while 'dead' cells had more red than green.

\section{Bacterial heterotrophic production}

Subsamples for the measurement of bulk leucine incorporation by bacteria were taken from the different treatments and treated using the method as outlined by Simon \& Azam (1989). Two $5 \mathrm{ml}$ samples and one $5 \mathrm{ml}$ formaldehyde-killed blank per treatment were inoculated with ${ }^{3} \mathrm{H}$-leucine $(20 \mathrm{nM}$ final concentration, Amersham, specific activity $160 \mathrm{Ci}$ $\mathrm{mmol}^{-1}$ ) and incubated in the dark at $20^{\circ} \mathrm{C}$ for $2 \mathrm{~h}$. Subsequently, the samples were fixed with formaldehyde ( $2 \%$ final concentration), filtered onto $0.2 \mu \mathrm{m}$ Millipore GTTP polycarbonate filters, and rinsed 3 times with $10 \mathrm{ml}$ of $5 \%$ ice-cold trichloroacetic acid. The filters were then transferred to scintillation vials and dried at room temperature. One $\mathrm{ml}$ of ethyl acetate and $8 \mathrm{ml}$ of scintillation cocktail (Packard Gold Insta Gel) were added to each vial. The vials were counted in an LKB liquid scintillation counter after $18 \mathrm{~h}$. The obtained disintegrations per minute (DPMs) were converted to leucine incorporation rates. Leucine incorporated into bacterial biomass was converted to bacterial carbon production using the empirical conversion factor $0.07 \times 10^{18} \mathrm{cells} \mathrm{mol}^{-1}$ Leu (Riemann et al. 1990) and assuming a $\mathrm{C}$ content of bacteria of $20 \mathrm{fg} \mathrm{C}^{\mathrm{C}} \mathrm{cell}^{-1}$ (Lee \& Fuhrman 1987). The application of this conversion factor resulted in similar bacterial heterotrophic production (BHP) estimates as with the theoretical factor of $1.55 \mathrm{~kg} \mathrm{C} \mathrm{mol}^{-1}$ Leu that assumes no isotope dilution (Simon \& Azam 1989). BHP divided by bacterial biomass provided estimates of the specific growth rate of bacteria $\left(\mathrm{d}^{-1}\right)$.

\section{Viral abundance}

Viral abundance was enumerated by flow cytometry (FC), which currently cannot be combined with virus-aggregate disruption agents such as methanol, since it interferes with the staining dye (Weinbauer et al. 2009). Thus, bulk measurements represent likely free viral abundance (FVA). In specific samples, viruses attached to BC particles were enumerated by epifluorescence microscopy (see below).

For viral counts by FC, we followed the optimized protocol by Brussaard (2004). Subsamples (2 ml) were fixed with glutaraldehyde $(0.5 \%$ final concentration), incubated at $4^{\circ} \mathrm{C}$ for 15 to $30 \mathrm{~min}$, and subsequently frozen in liquid nitrogen and stored at $-80^{\circ} \mathrm{C}$. Upon thawing, viruses were stained with SYBR Green I (Molecular Probes, Invitrogen) at a final concentration of $0.5 \times 10^{-4}$ of the commercial stock at $80^{\circ} \mathrm{C}$ for $10 \mathrm{~min}$ and quantified using a FACSCalibur (Becton and Dickinson) flow cytometer after dilution with TE buffer (10 mM Tris, 1 mM EDTA, pH 8).

\section{Viral production}

Viral production (VP) was estimated for selected samples using the virus reduction technique (Weinbauer et al. 2010). The rationale behind the virus reduction approach is to reduce virus abundance and thereby essentially prevent new viral infection. Thus, the viruses produced originate from already infected cells. Bacteria from $200 \mathrm{ml}$ of raw seawater were concentrated using a $0.2 \mu \mathrm{m}$ pore size tangential flow system (VIVAFLOW 50). To obtain virus-free seawater, the $0.2 \mu \mathrm{m}$ pore-size ultrafiltrate was passed through a $100 \mathrm{kDa}$ cartridge (VIVAFLOW 50). The bacterial concentrates were brought up to the original volume with virus-free seawater and incubated in duplicate $50 \mathrm{ml}$ Falcon tubes (BD Biosciences) at $20 \pm 2^{\circ} \mathrm{C}$ for $24 \mathrm{~h}$. At $\mathrm{t}_{0}$ of the experiments, 2 additional tubes were amended with mitomycin C (Sigma) at a final concentration of $1 \mu \mathrm{g} \mathrm{ml}^{-1}$ in order to induce the lytic cycle in prophages. Subsamples $(2 \mathrm{ml})$ for viral abundance were taken every 3 to $4 \mathrm{~h}$ from each incubation, fixed with glutaraldehyde ( $0.5 \%$ final concentration), incubated at $4^{\circ} \mathrm{C}$ for 15 to $30 \mathrm{~min}$, subsequently frozen in liquid nitrogen and stored at $-80^{\circ} \mathrm{C}$ until counted by flow cytometry. Lytic VP was calculated as the increase in viral abundance over short time intervals $(\sim 4 \mathrm{~h})$. An increase in viral abundance in the mitomycin C treatments represents lytic + lysogenic production (Paul \& Weinbauer 2010, Weinbauer et al. 2010). VP was corrected for the changes in bacterial 
abundance in the VP assays. Dividing the number of produced phages by an assumed burst size (BS) of 50 (Parada et al. 2006) yields the number of lysed cells and gives an estimate of the fraction of infected cells (FIC) when divided by the bacterial abundance at the start of the experiment (Weinbauer et al. 2002). Lysis rates were calculated by dividing VP by BS and were used to calculate virus-mediated mortality (VMM) as a percentage of bacterial standing stock (BSS) per day or as a fraction of BHP. Alternatively, VMM was related to FIC using the model by Binder (1999).

\section{BC particle size and attachment of viruses and bacteria}

Associations between BC particles, bacteria, and viruses were investigated by epifluorescence and confocal laser scanning microscopy (CLSM), respectively, in experiment $B C$-grad following the protocol of Cattaneo et al. (2010). The size and number of colonized particles were high enough to allow enumeration only in the treatment with the addition of $\mathrm{BC}$ at the highest concentration $\left(2000 \mu \mathrm{g} \mathrm{l}^{-1}\right)$. Slides were prepared using a slightly modified version of the Noble and Fuhrman procedure (Noble \& Fuhrman 1998). Subsamples of $2 \mathrm{ml}$ were fixed with glutaraldehyde ( $0.5 \%$ final concentration) at $4^{\circ} \mathrm{C}$ for 15 to $30 \mathrm{~min}$, frozen in liquid nitrogen, and stored at $-80^{\circ} \mathrm{C}$ until analysis. Thawed samples were filtered onto $0.02 \mu \mathrm{m}$ pore size $\mathrm{AlO}_{3}$ filters $(25 \mathrm{~mm}$ diameter, Anodisc, Whatman) by low-pressure filtration and stained with SYBR Gold (Molecular Probes, Invitrogen) diluted 1000-fold in autoclaved and $0.2 \mu \mathrm{m}$ filtered MilliQ water. The filters were transferred onto slides with a mounting solution $(0.1 \% p$-phenylendiamine; freshly made from a frozen $10 \%$ aqueous stock Sigma-Aldrich, P-1519) in 50\% glycerol-50\% phosphate-buffered saline (PBS, $0.05 \mathrm{M} \mathrm{Na}_{2} \mathrm{PO}_{4}$, $\left.0.85 \% \mathrm{NaCl}_{1} \mathrm{pH} 7.5\right)$ and Vectashield (1:6 v:v; Vector, Burlingame). The slides were stored at $-20^{\circ} \mathrm{C}$ until examined under the CLSM.

Initially, abundances of free and BC-attached viruses and bacteria were assessed at 1200-fold magnification with an epifluorescence microscope (Axiophot, Carl Zeiss). At least 25 microscopic fields were inspected. Colonized BC particles were then investigated with a CLSM (Leica SP2) equipped with an argon neon laser (excitation: $488 \mathrm{~nm}$; emission spectrum: $530-550 \mathrm{~nm})$. For each particle, stacks of images were acquired and 3-dimensional surfaces were measured for each particle as previously described (Cattaneo et al. 2010). The surface area of particles was converted into ESD (i.e. the diameter of spheres with equivalent volume to nonsphericalshaped particles; Peduzzi \& Weinbauer 1993). We quantified the abundance of attached viruses and bacteria, and manual counting was preferentially used over automated counting to ensure the required accuracy of the measurements (Luef et al. 2009, Cattaneo et al. 2010).

\section{Statistics}

All statistical analyses were performed with JMP 7.0 (SAS). The Shapiro-Wilk $W$-test was used to check for normal distribution of data. Analysis of covariance (ANCOVA) and 1-way ANOVA for normal distributions and Kruskal-Wallis tests for nonnormal distributions were used to evaluate the differences between treatments. Spearman rank correlation for nonparametric data was performed to determine the relationships between the various parameters measured.

\section{RESULTS}

\section{Effects of BC on nutrients and DOC}

The addition of $\mathrm{BC}$ resulted in differences in inorganic nutrients and DOC concentrations between treatments already at $\mathrm{t}_{0}$ : light-exposed $\mathrm{BC}$ additions produced a significant increase in DOC concentration in experiment $B C$-fix (ANCOVA, $\mathrm{p}<0.05$ ) compared to the $\mathrm{BC}$-free control. Phosphate concentrations were higher in $\mathrm{BC}$ incubations than in the $\mathrm{BC}$-free control, although the differences were only significant in experiment $B C$-grad. In both experiments, average ammonium concentrations were 5 - to 6 -fold higher with $\mathrm{BC}$ additions than in the controls (ANCOVA, $\mathrm{p}<0.05$, Table 1). In most cases, nutrient concentrations did not change significantly over the course of the experiments, but ammonium and nitrate concentrations in experiment $B C$-fix and nitrite concentration in experiment $B C$-grad increased (ANCOVA, Table 1).

\section{Total BA and the number of active bacteria}

In both experiments, BA did not vary significantly with time in the $\mathrm{BC}$-free control nor in the treatment with the addition of $200 \mu \mathrm{g} \mathrm{BC} \mathrm{l}^{-1}$ (ANCOVA, Table 2, Fig. 2). However, BA increased with time and $\mathrm{BC}$ con- 
Table 1. Mean \pm SD values of the nutrient and dissolved organic carbon (DOC) concentrations ( $\mu$ M) analyzed in each of the different treatments as well as results of analyses of covariance with time (BC-fix) and with time and black carbon (BC) concentration $(B C$-grad) as covariates. Values are averaged over the experimental time $(\mathrm{n}=24)$. Significantly different values are highlighted in bold: ${ }^{* *} \mathrm{p}<0.001,{ }^{*} \mathrm{p}<0.05$; ns: not significant. Treatments are as follows: BC-free: $\mathrm{BC}$-free control; BC-dark:

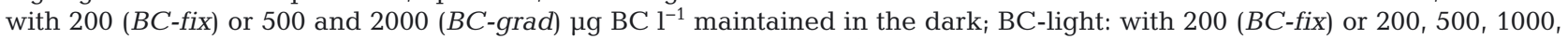

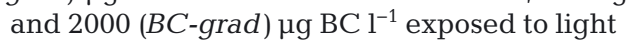

\begin{tabular}{|c|c|c|c|c|c|c|}
\hline Experiment & Treatment & $\mathrm{PO}_{4}{ }^{3-}$ & $\mathrm{NH}_{4}{ }^{+}$ & $\mathrm{NO}_{2}^{-}$ & $\mathrm{NO}_{3}^{-}$ & DOC \\
\hline \multirow[t]{3}{*}{$B C$-fix } & BC-free & $0.11 \pm 0.02$ & $0.14 \pm 0.03^{* *}$ & $0.01 \pm 0.005$ & $0.08 \pm 0.02$ & $81.3 \pm 3.4$ \\
\hline & BC-dark & $0.16 \pm 0.03$ & $0.87 \pm 0.23$ & $0.02 \pm 0.003$ & $0.09 \pm 0.03$ & $80.9 \pm 4.7$ \\
\hline & BC-light & $0.15 \pm 0.03$ & $0.93 \pm 0.42$ & $0.02 \pm 0.01$ & $0.11 \pm 0.04$ & $91.1 \pm 13.6^{*}$ \\
\hline Covariate & Time & ns & ${ }^{*}$ & ns & ${ }^{*}$ & ns \\
\hline \multirow[t]{3}{*}{$B C$-grad } & BC-free & $0.10 \pm 0.00^{*}$ & $0.17 \pm 0.10^{*}$ & $0.02 \pm 0.02$ & $0.07 \pm 0.02$ & $80.3 \pm 3.8$ \\
\hline & BC-dark & $0.14 \pm 0.02$ & $0.76 \pm 0.50$ & $0.04 \pm 0.01$ & $0.12 \pm 0.05$ & $83.0 \pm 6.1$ \\
\hline & BC-light & $0.16 \pm 0.03$ & $0.90 \pm 0.59$ & $0.04 \pm 0.01$ & $0.10 \pm 0.03$ & $83.6 \pm 9.0$ \\
\hline \multirow[t]{2}{*}{ Covariate } & Time & ns & ns & $*$ & ns & ns \\
\hline & $\mathrm{BC}$ concentration & ns & ns & ns & ns & ns \\
\hline
\end{tabular}

Table 2. Mean \pm SD values of organism abundance and activity analyzed in each of the different treatments as well as results of analyses of covariance with time (BC-fix) and time and black carbon (BC) concentration (BC-grad) as covariates. Values are averaged over experimental time. Significantly different values are highlighted in bold: ${ }^{* * *} \mathrm{p}<0.0001,{ }^{* *} \mathrm{p}<0.001,{ }^{*} \mathrm{p}<0.05$. Treatments as in Table 1. BHP: bacterial heterotrophic production; BA: total bacterial abundance; PAB: particle-attached bacteria; CTC: 5-cyano-2,3-ditolyl tetrazolium chloride reducing cells; LIVE: membrane-intact cells using the nucleic acid double staining protocol (see Materials and Methods); FVA: free viral abundance

\begin{tabular}{|c|c|c|c|c|c|c|c|}
\hline Experiment & Treatment & BHP $\mu \mathrm{g} \mathrm{Cl}^{-1} \mathrm{~d}^{-1}$ & $\mathrm{BA} \times 10^{5} \mathrm{ml}^{-1}$ & PAB \% & СТC \% & LIVE \% & $\mathrm{FVA} \times 10^{6} \mathrm{ml}^{-1}$ \\
\hline$B C$-fix & $\begin{array}{l}\text { BC-free } \\
\text { BC-dark } \\
\text { BC-light }\end{array}$ & $\begin{array}{l}1.7 \pm 0.2 \\
1.9 \pm 0.1 \\
\mathbf{3 . 0} \pm \mathbf{0 . 8 ^ { * * * }}\end{array}$ & $\begin{array}{l}2.0 \pm 0.2 \\
2.2 \pm 0.2 \\
2.2 \pm 0.2\end{array}$ & $\begin{array}{l}- \\
-\end{array}$ & $\begin{array}{l}62 \pm 11 \\
64 \pm 13 \\
\mathbf{5 6} \pm \mathbf{1 3}^{*}\end{array}$ & $\begin{array}{l}83 \pm 4^{* * *} \\
\mathbf{7 8} \pm \mathbf{6} \\
\mathbf{7 5} \pm \mathbf{6}\end{array}$ & $\begin{array}{l}12.7 \pm 0.5^{*} \\
\mathbf{1 1 . 3} \pm \mathbf{0 . 8} \\
\mathbf{1 1 . 5} \pm \mathbf{0 . 7}\end{array}$ \\
\hline Covariate & Time & $*$ & ns & - & * & ns & ns \\
\hline$B C$-grad & $\begin{array}{l}\text { BC-free } \\
\text { BC-dark } \\
\text { BC-light }\end{array}$ & $\begin{array}{l}1.7 \pm 0.4 \\
2.4 \pm 1.2 \\
2.6 \pm 1.5\end{array}$ & $\begin{array}{l}1.5 \pm 0.1 \\
1.8 \pm 0.4 \\
1.8 \pm 0.3\end{array}$ & $\begin{aligned} 6 & \pm 1^{* * *} \\
49 & \pm 10 \\
47 & \pm 10\end{aligned}$ & $\begin{array}{l}49 \pm 23 \\
54 \pm 11 \\
54 \pm 16\end{array}$ & $\begin{array}{l}72 \pm 4 \\
76 \pm 6 \\
75 \pm 5\end{array}$ & $\begin{aligned} 12.7 & \pm 0.7^{* *} \\
\mathbf{7 . 3} & \pm 1.7 \\
\mathbf{8 . 2} & \pm \mathbf{2 . 2}\end{aligned}$ \\
\hline Covariate & $\begin{array}{c}\text { Time } \\
\text { BC concentration }\end{array}$ & $\stackrel{*}{* * *}$ & $\stackrel{* *}{* * *}$ & $\stackrel{*}{* * *}$ & $\begin{array}{l}* * * \\
\mathrm{~ns}\end{array}$ & $\stackrel{* * *}{*}$ & $\mathrm{~ns}_{* * *}$ \\
\hline
\end{tabular}

centration in the other treatments (ANCOVA, p < 0.0001 , Table 2, Fig. 2B), reaching $78 \%$ higher BA in the light-exposed and $68 \%$ higher $\mathrm{BA}$ in the darkexposed BC treatment at $2000 \mu \mathrm{g} \mathrm{BC} \mathrm{l}^{-1}$ with respect to initial values. The percentage of actively respiring cells that reduced 5-cyano-2,3-ditolyl tetrazolium chloride (CTC) was significantly lower in the BC-light treatment than in all other treatments in experiment $B C$-fix (ANCOVA, $\mathrm{p}<0.05$, Table 2). The percentage of membrane-intact cells (LIVE) was significantly lower in the $\mathrm{BC}$ treatments than in the control in $B C$ fix, but increased slightly with $\mathrm{BC}$ concentration and time in BC-grad (ANCOVA, p $<0.0001$, Table 2).

\section{Abundance of free viruses}

Initial free viral abundance (FVA) as measured by flow cytometry was $1.26 \times 10^{7}$ and $1.16 \times 10^{7}$ viruses $\mathrm{ml}^{-1}$ in experiments $B C$-fix and $B C$-grad, respectively. In the $\mathrm{BC}$-free controls, these values remained roughly stable from $t_{0}$ throughout the experiment $B C$-fix (Fig. 3A) while in BC-grad they increased by $8 \%$ until $t_{8 \mathrm{~h}}$ and then stayed approximately unchanged until the end (Fig. 3B). Upon $\mathrm{BC}$ amendment, FVA decreased from $t_{0}$ in both experiments and remained roughly constant after the first sampling $8 \mathrm{~h}$ later (Fig. 3). In $B C$-fix, this decrease amounted to $13 \%$ with respect to the $\mathrm{BC}$ free controls. After $80 \mathrm{~h}, \mathrm{FVA}$ increased in all treatments and finally leveled off at ca. $1.34 \pm 0.09$ (range) $\times 10^{7}$ viruses $\mathrm{ml}^{-1}$ in the controls, and at $1.27 \pm 0.03 \times 10^{7}$ and $1.29 \pm 0.03 \times 10^{7}$ viruses $\mathrm{ml}^{-1}$ in the light and dark BC treatments, respectively. Average FVA was significantly lower in the $\mathrm{BC}$ treatments than in the $\mathrm{BC}$-free controls and was not influenced by BC light exposure (Table 1, Fig. 3A, ANCOVA, $p<0.05$ ). 


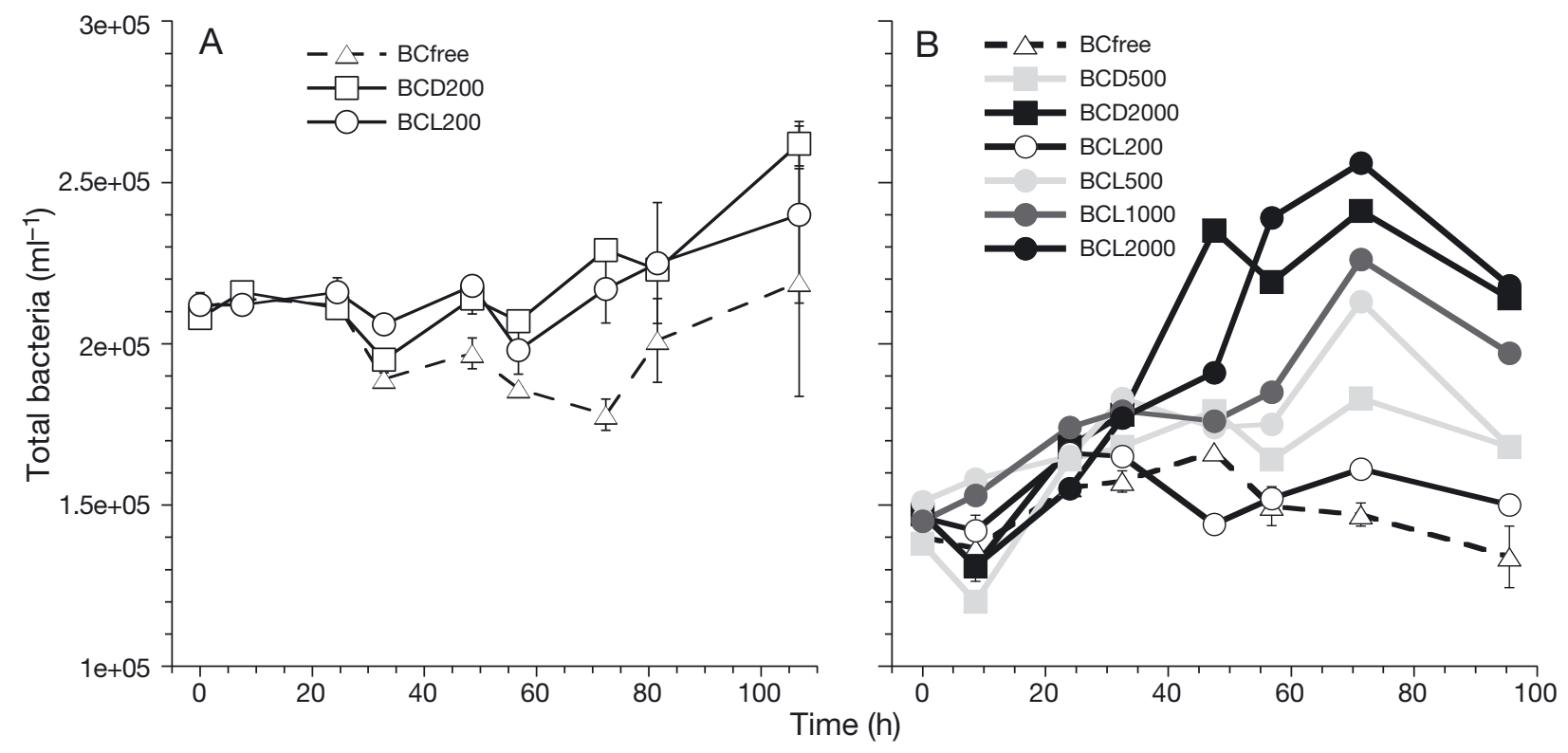

Fig. 2. Bacterial abundance in experiments (A) BC-fix and (B) BC-grad with addition of light-exposed (BCL) und non-exposed (BCD) black carbon (BC) and under control treatments (BCfree). Values are averages from duplicate treatments and error bars are the ranges in experiment $B C$-fix and in the $\mathrm{BC}$ controls of experiment $B C$-grad. $\mathrm{BC}$ concentrations are indicated $\left(\mu \mathrm{g} \mathrm{l}^{-1}\right)$
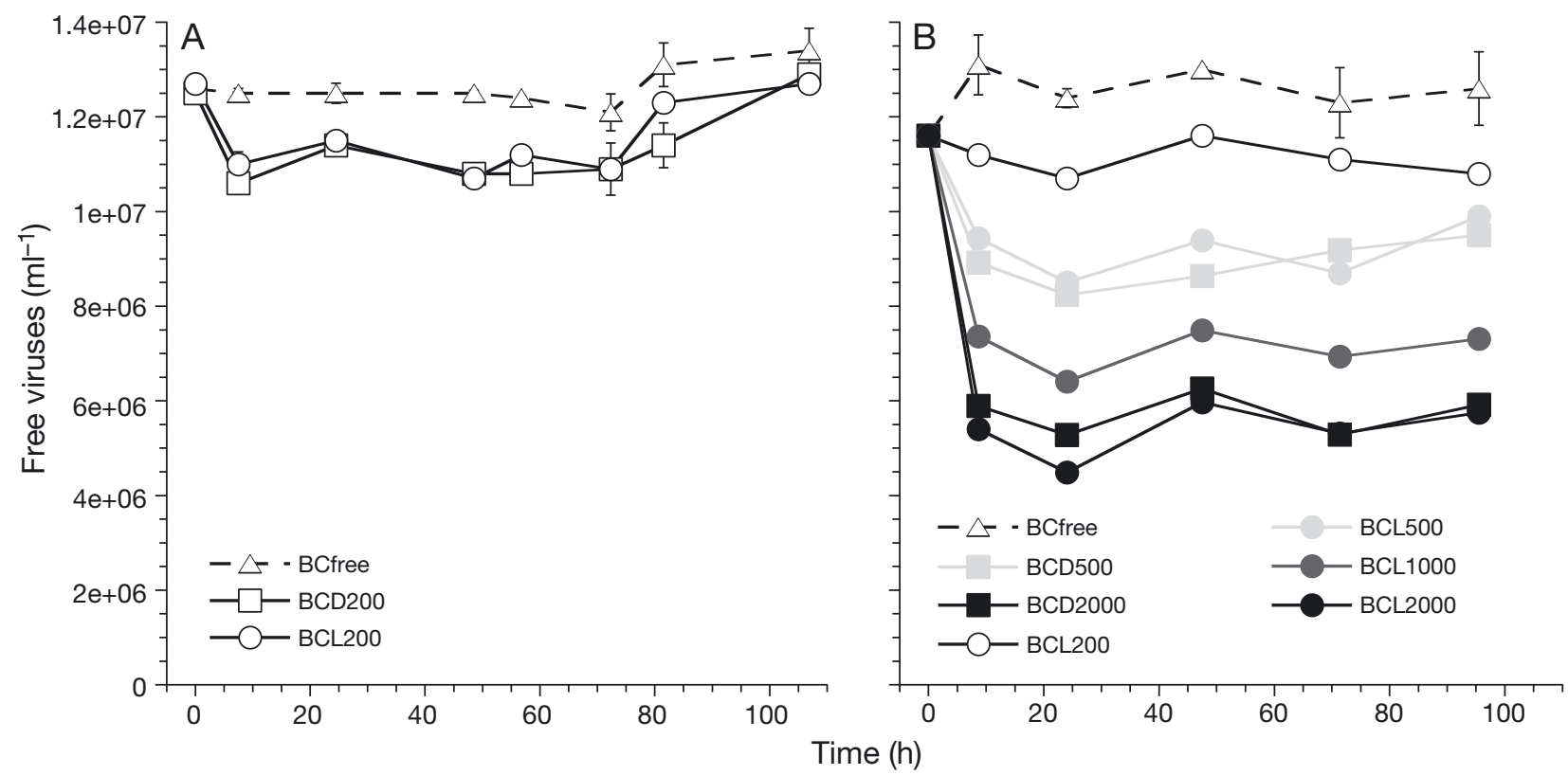

Fig. 3. As in Fig. 2, but for the abundance of free viruses in experiments (A) $B C$-fix and (B) $B C$-grad. Where not visible, error bars are contained within the symbol

In experiment $B C$-grad, FVA averaged over the experimental time decreased with increasing $\mathrm{BC}$ concentrations (ANCOVA, $\mathrm{p}<0.0001$ ) but was not influenced by BC light exposure (Table 2, Fig. 4B).
The virus-to-bacteria ratio (VBR) ranged from 21 to 109 and averaged $56 \pm 16$ without differences between experiments. VBR was significantly lower with $\mathrm{BC}$ addition only in the experiment BC-grad (47 vs. 88, ANCOVA, p $<0.05$, 


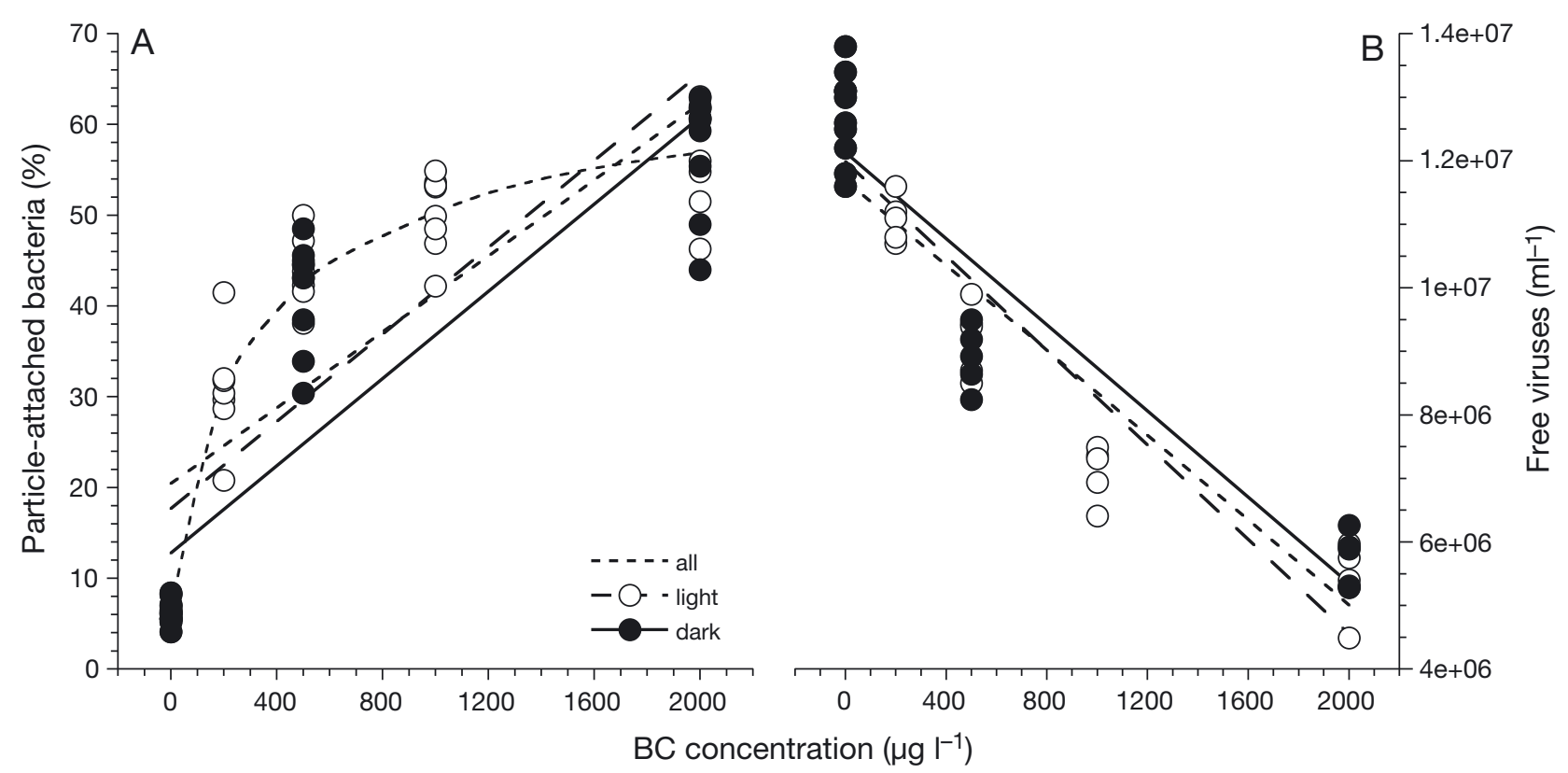

Fig. 4. (A) Percentage of particle-attached bacteria (PAB) and (B) abundance of free viruses (FVA) in relation to black carbon (BC) concentration in experiment $B C$-grad. When interpolating all data, it is apparent that BC particles were becoming saturated at a $\mathrm{BC}$ concentration of $1000 \mu \mathrm{gC}^{-1}$, and at most about half of the bacteria were becoming attached. $\mathrm{PAB}$ increased with $\mathrm{BC}$ concentration, while FVA decreased with $\mathrm{BC}$ concentration: all $\mathrm{PAB}=20 \%+0.02 \mathrm{BC}$ concentration $\left(\mathrm{R}^{2}=0.67\right)$; light $\mathrm{BC}$ treatment: $\mathrm{PAB}=18 \%+0.02 \mathrm{BC}$ concentration $\left(\mathrm{R}^{2}=0.69\right)$; dark $\mathrm{BC}$ treatment: $\mathrm{PAB}=13 \%+0.02 \mathrm{BC}$ concentration $\left(\mathrm{R}^{2}=\right.$ $0.77)$; Virus: all FVA $=1.17 \times 10^{7}-3344 \mathrm{BC}$ concentration $\left(\mathrm{R}^{2}=0.87\right)$; light $\mathrm{BC}$ treatment: FVA $=1.20 \times 10^{7}-3721 \mathrm{BC}$ concentration $\left(\mathrm{R}^{2}=0.88\right)$; dark $\mathrm{BC}$ treatment: $\mathrm{FVA}=1.21 \times 10^{7}-3395 \mathrm{BC}$ concentration $\left(\mathrm{R}^{2}=0.88\right)$

covariates: $\mathrm{BC}$ concentration: $\mathrm{p}<0.0001$, time: non-significant).

\section{BC-attached viruses and bacteria and size of the BC particles}

In $B C$-grad, the size of BC particles with attached bacteria and viruses as analyzed by CLSM ranged from 4.6 to $22.4 \mu \mathrm{m}$ ESD (average: $9.5 \pm 5.4 \mu \mathrm{m}$ ), but $58 \%$ of the particles were smaller than $10 \mu \mathrm{m}$ ESD throughout the experiment except $t_{0}$ (details not shown). Fifty-six percent of the particles had fewer than 10 attached bacteria. The abundance of attached bacteria was positively related to $\mathrm{BC}$ particle size $\left(B A=-0.03+0.94 E S D, n=16, R^{2}=0.38\right.$, Table 3), and the average number of bacteria per ESD was $0.9 \pm 0.7 \mu^{-1}$. The number of BC-attached viruses ranged between 4 and 64 viruses per particle. A positive correlation was observed between the abundance of $\mathrm{BC}$-attached viruses and $\mathrm{BC}$ particle size, while the number of $\mathrm{BC}$-attached viruses per $\mu \mathrm{m}^{2}$ was negatively correlated with BC particle size (Table 3).

At the end of the incubation, in the treatment with the addition of $\mathrm{BC}$ at the highest concentration
Table 3. Spearman rank correlation analysis of microbial abundances with black carbon $(\mathrm{BC})$ particle size from the treatments with the addition of $2000 \mu \mathrm{g} \mathrm{BC} \mathrm{^{-1 }}$ kept in the dark in experiment $B C$-grad. VBR: virus-to-bacteria ratio; ns: not significant

\begin{tabular}{|cccc|}
\hline & $\rho$ & $\mathrm{n}$ & $\mathrm{p}$ \\
\hline $\begin{array}{c}\text { Abundance of attached: } \\
\text { viruses particle }\end{array}$ & & & \\
${\text { viruses } \mu \mathrm{m}^{-1}}_{\text {bacteria particle }}^{-1}$ & 0.640 & 18 & $<0.05$ \\
${\text { bacteria } \mu \mathrm{m}^{-2}}^{\text {VBR } \mu \mathrm{m}^{-2}}$ & -0.612 & 18 & $<0.05$ \\
& -0.415 & 16 & $<0.05$ \\
& -0.738 & 16 & $\mathrm{~ns}$ \\
& & & $<0.05$ \\
\hline
\end{tabular}

$\left(2000 \mu \mathrm{g} \mathrm{l}^{-1}\right), \mathrm{BC}$-attached viruses assessed by epifluorescence microscopy accounted for $40 \%$ of total viral abundance, and attached bacteria accounted for $50 \%$ of the total bacterial abundance. The percentage of particle-attached bacteria measured using the FC approach was only recorded in BC-grad and ranged from $4-8 \%$ in the $\mathrm{BC}$-free controls (average $6 \pm 1 \%$, considered to be the background counts of the technique), to $44-63 \%$ (average $57 \pm 6 \%$ ) at $2000 \mu \mathrm{g} \mathrm{BC} \mathrm{l}^{-1}$. The percentage of particle-attached bacteria increased significantly with increasing BC concentration (Fig. 4A, Table 2). Furthermore, per- 
centage of particle-attached bacteria correlated positively and significantly with bacterial production $(\rho=0.335, \mathrm{n}=55, \mathrm{p}<0.05)$ and with the $\%$ HNA $(\rho=$ $0.310, \mathrm{n}=55, \mathrm{p}<0.05)$. No effect of exposure to artificial solar radiation of $\mathrm{BC}$ on the percentage of particle-attached bacteria was detected.

\section{Bacterial heterotrophic production}

In $B C$-fix, the addition of irradiated BC led to a significant increase in $\mathrm{BHP}$ with respect to the other treatments after $24 \mathrm{~h}$ (ANCOVA, p < 0.0001), and this level of activity was maintained throughout the experiment (Fig. 5A). In contrast, BHP in the BC-dark treatment was not significantly different from the BC-free controls and increased by only $32 \%$ (vs. $148 \%$ in treatment BC-light, Fig. 5A).

In BC-grad, BHP increased significantly with increasing $\mathrm{BC}$ concentrations in all BC treatments (Table 2, Fig. 5B). BHP amended with light-exposed $\mathrm{BC}$ was up to 12 times higher than the initial BHP of $0.7 \mu \mathrm{g} \mathrm{C}^{-1} \mathrm{~d}^{-1}$, whereas BHP in the dark BC treatment was only higher than the $\mathrm{BC}$-free control at the

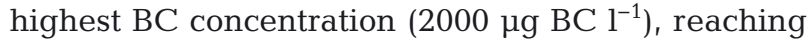
$5 \mu \mathrm{g} \mathrm{C} \mathrm{l}^{-1} \mathrm{~d}^{-1}$. Time-averaged BHP for the time interval of 2 to $3 \mathrm{~d}$ was significantly higher with the addition of light-exposed $\mathrm{BC}$ than in the other treatments
(ANCOVA, $\mathrm{p}<0.05)$. The specific growth rate of bacteria showed the same trend as BHP in both experiments (details not shown).

\section{Viral production and infection}

VP was measured at $t_{0}$ and after $2 \mathrm{~d}$ in all treatments of experiment BC-fix. In BC-grad, VP was measured only in some of the treatments (Table 4). Tangential flow filtration through a $100 \mathrm{kDa}$ cartridge removed viruses efficiently, resulting in $<1 \%$ of the original viral abundance. At $t_{0}$, viral abundance in the VP incubations ranged between 9 and $40 \%$ of the original viral abundance. These viruses were introduced along with the bacterial concentrate into the incubations for estimating VP.

In $B C$-fix, lytic VP increased from $1.3 \pm 0.3 \times 10^{6}$ viruses ml $\mathrm{ml}^{-1} \mathrm{~d}^{-1}$ at $\mathrm{t}_{0}$ to $2.7-24.3 \times 10^{6}$ viruses $\mathrm{ml}^{-1} \mathrm{~d}^{-1}$ after $2 \mathrm{~d}$ of incubation (Table 4 ). VP was significantly lower in the dark $\mathrm{BC}$ treatments compared to the $\mathrm{BC}$ control and the light-exposed BC treatments (Table 4, Kruskal-Wallis test, $\mathrm{p}<0.05)$. At $\mathrm{t}_{0}, 12 \pm 2 \%$ bacteria were infected, corresponding to an estimated viral

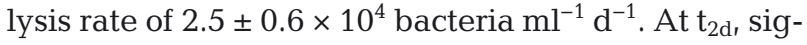
nificantly fewer bacteria were infected in the dark BC treatment than in the $\mathrm{BC}$ control and in the light $\mathrm{BC}$ treatment, and estimated viral lysis rates were signifi-

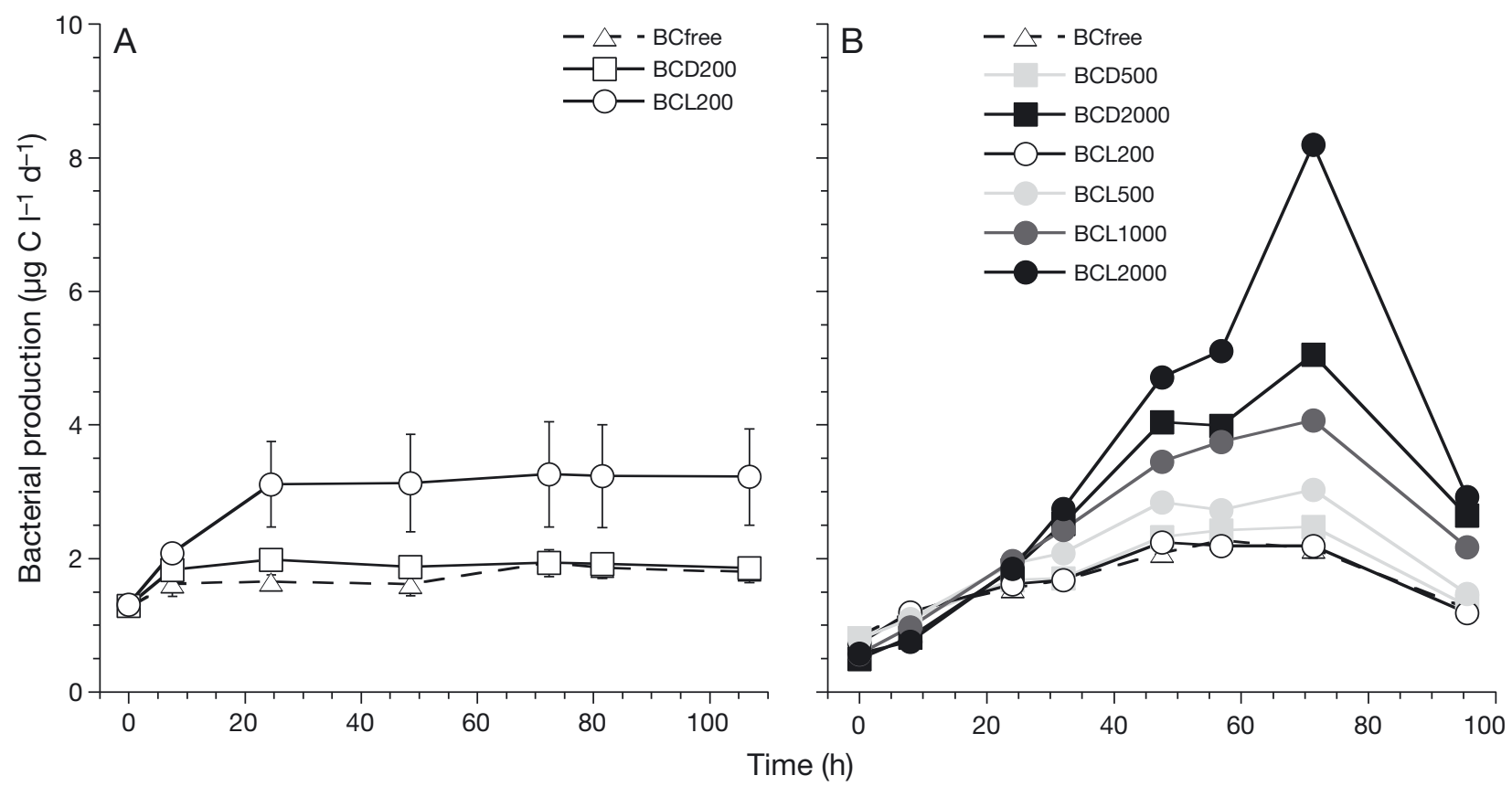

Fig. 5. Bacterial heterotrophic production in experiments (A) BC-fix and (B) BC-grad with addition of light-exposed (BCL) und non-exposed (BCD) black carbon (BC) and under control treatments (BCfree). Values are averages from duplicate treatments and error bars are the ranges in experiment $B C$-fix and in the $\mathrm{BC}$ controls of experiment $B C$-grad. $\mathrm{BC}$ concentrations are indicated $\left(\mu \mathrm{g}^{-1}\right)$ 
Table 4. Viral production (VP, viruses $\mathrm{ml}^{-1} \mathrm{~d}^{-1}$ ), frequency of infected cells (FIC, \%), bacterial lysis rates and virally mediated loss of bacterial standing stock $\left(\mathrm{VMM}_{\mathrm{SS}}, \% \mathrm{~d}^{-1}\right.$ ) and viral mediated mortality related to FIC (VMM, \%) by a model (Binder 1999). Data are given as means \pm range of duplicate measurements. Significantly different values for treatments are highlighted in bold $(\mathrm{p}<0.05$, Kruskal-Wallis test). Treatments as in Table 1

\begin{tabular}{|c|c|c|c|c|c|c|c|}
\hline Experiment & $\begin{array}{l}\text { Time } \\
\text { (d) }\end{array}$ & Treatment & $\begin{array}{c}\mathrm{VP} \times \\
10^{6} \mathrm{ml}^{-1} \mathrm{~d}^{-1}\end{array}$ & FIC $\%$ & $\begin{array}{l}\text { Lysis rate } \times \\
10^{4} \mathrm{ml}^{-1} \mathrm{~d}^{-1}\end{array}$ & $\begin{array}{l}\mathrm{VMM}_{\mathrm{SS}} \\
\% \mathrm{~d}^{-1}\end{array}$ & VMM \% \\
\hline \multirow[t]{4}{*}{$B C$-fix } & 0 & & $1.3 \pm 0.2$ & $12 \pm 2$ & $2.5 \pm 0.4$ & $12 \pm 2$ & $25 \pm 4$ \\
\hline & 2 & BC-free & $9.9 \pm 2.9$ & $20 \pm 5$ & $19.7 \pm 5.8$ & $101 \pm 26$ & $46 \pm 17$ \\
\hline & & BC-dark & $3.6 \pm 0.9$ & $10 \pm 3$ & $7.2 \pm 1.8$ & $34 \pm 9$ & $21 \pm 8$ \\
\hline & & BC-light & $15.4 \pm 9.5$ & $27 \pm 16$ & $30.8 \pm 19.1$ & $140 \pm 85$ & $88 \pm 68$ \\
\hline \multirow[t]{5}{*}{$B C$-grad } & 0 & & $2.0 \pm 0.9$ & $8 \pm 3$ & $4.0 \pm 1.8$ & $28 \pm 12$ & $16 \pm 7$ \\
\hline & 2 & BC-free & $15.2 \pm 1.8$ & $25 \pm 2$ & $30.5 \pm 3.5$ & $183 \pm 21$ & $63 \pm 8$ \\
\hline & & BC-dark 500 & $2.2 \pm 2.2$ & $3 \pm 3$ & $4.4 \pm 4.4$ & $24 \pm 24$ & $6 \pm 6$ \\
\hline & & BC-light 500 & $6.2 \pm 0.6$ & $9 \pm 1$ & $12.3 \pm 1.2$ & $71 \pm 7$ & $19 \pm 2$ \\
\hline & & BC-light 2000 & $1.3 \pm 1.3$ & $2 \pm 2$ & $2.7 \pm 2.7$ & $14 \pm 14$ & $3 \pm 3$ \\
\hline
\end{tabular}

cantly lower in BC-dark $\left(7.2 \pm 1.8 \times 10^{4}\right.$ bacteria $\mathrm{ml}^{-1}$ $\left.\mathrm{d}^{-1}\right)$ than in the other treatments $\left(26.0 \pm 15.1 \times 10^{4}\right.$ bacteria $\mathrm{ml}^{-1} \mathrm{~d}^{-1}$, Table 4, Kruskal-Wallis test, $\mathrm{p}<0.05$ ). Virus-mediated mortality of bacterial standing stock per day $\left(\mathrm{VMM}_{\mathrm{SS}}\right)$ varied between $12 \% \mathrm{~d}^{-1}$ at $\mathrm{t}_{0}$ and $>100 \% \mathrm{~d}^{-1}$ in the light-exposed BC treatment at $\mathrm{t}_{2 \mathrm{~d}}$ and was significantly lower in the dark BC treatment than in the light-exposed $\mathrm{BC}$ treatment and the $\mathrm{BC}$ control (Table 4, Kruskal-Wallis test, $\mathrm{p}<0.05$ ). The estimated virally mediated loss of BHP ranged from $33 \%$ at $\mathrm{t}_{0}$ to $>100 \%$ in the light-exposed $\mathrm{BC}$ treatment and BC-free control without significant differences between treatments. Following the model by Binder (1999), VMM ranged from $7 \%$ in the dark-exposed $\mathrm{BC}$ treatment to $>100 \%$ in the light-exposed BC treatment without differences between treatments.

In $B C$-grad, lytic VP increased from $2.0 \pm 0.9 \times 10^{6}$ at $\mathrm{t}_{0}$ to $15.2 \pm 1.8 \times 10^{6}$ viruses $\mathrm{ml}^{-1} \mathrm{~d}^{-1}$ at $\mathrm{t}_{2 \mathrm{~d}}$ in the $\mathrm{BC}$ free control and was significantly higher than in the $\mathrm{BC}$-amended treatments $\left(3.2 \pm 2.8 \times 10^{6}\right.$ viruses $\mathrm{ml}^{-1}$ $\mathrm{d}^{-1}$, Table 4, Fig. 6, Kruskal-Wallis test, $\mathrm{p}<0.05$ ). At $t_{0}, 8 \pm 3 \%$ of bacteria were infected. At $t_{2 d}$, FIC was significantly higher in the $\mathrm{BC}$-free control than in the BC-amended treatments (Table 4, Kruskal-Wallis test, $\mathrm{p}<0.05)$. Consequently, estimated viral lysis rates were, on average, lower with $\mathrm{BC}$ addition $(6.5 \pm$ $5.7 \times 10^{7}$ bacteria $\mathrm{ml}^{-1} \mathrm{~d}^{-1}$ ) than in the BC-free control (Table 4, Kruskal-Wallis test, $\mathrm{p}<0.05$ ). The resulting $\mathrm{VMM}_{\mathrm{SS}}$ values were significantly lower in the presence of $\mathrm{BC}$ (on average $36 \pm 33 \% \mathrm{~d}^{-1}$ ) compared to the control $\left(>100 \% \mathrm{~d}^{-1}\right.$, Table 4, Kruskal-Wallis test, $\mathrm{p}<0.05)$. According to the model by Binder (1999) VMM was significantly lower with $\mathrm{BC}$ addition $(9 \pm$ $9 \%)$ than in the BC-free control $(63 \pm 8 \%$ Table 4 , Kruskal-Wallis test, $\mathrm{p}<0.05)$. No lysogens could be induced by mitomycin $\mathrm{C}$ in any of the experiments.

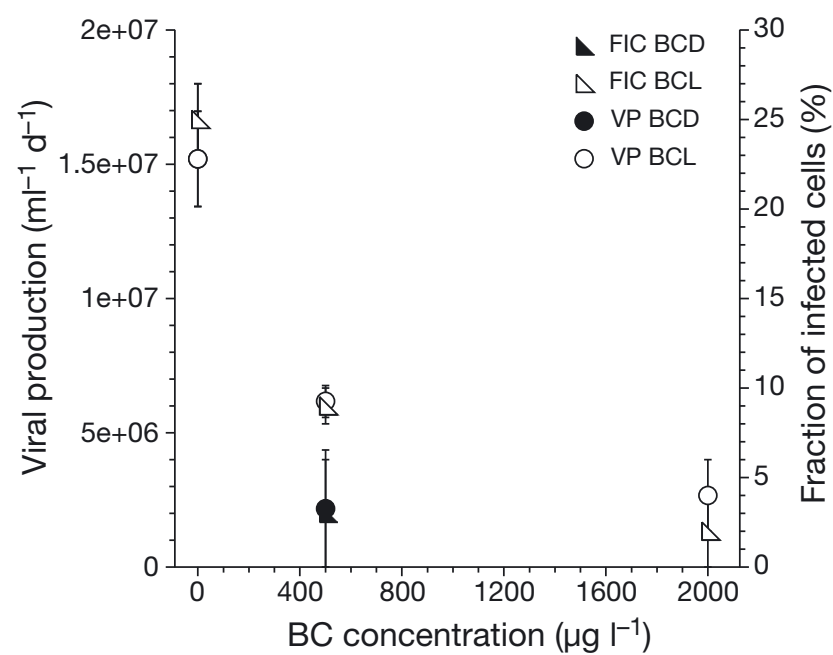

Fig. 6. Viral production (VP, viruses $\mathrm{ml}^{-1} \mathrm{~d}^{-1}$ ) and the fraction of infected cells (FIC, \%) in experiment $B C$-grad from Day 2 as a function of black carbon (BC) concentration. Values are averages of duplicates from the virus reduction approach to measure VP and FIC, and error bars are the ranges. BCL: light-exposed $\mathrm{BC}_{i} \mathrm{BCD}$ : non-exposed $\mathrm{BC}$

\section{DISCUSSION}

The effects of BC on bacterial abundance, production, and viral-mediated loss of bacterial production were assessed in this study using BC reference material and aged marine microbial communities. The main findings were that (1) BC addition increased bacterial biomass accumulation and reduced VP and infection and (2) exposure of BC to UV light increased bacterial production. These results suggest a stimulating effect of $\mathrm{BC}$ on aggregation processes and bacterial production and a suppressing effect on the viral shunt and associated nutrient regeneration with the potential to increase system heterotrophy. 


\section{Interaction between microorganisms and BC particles}

With the help of flow cytometry, we detected an additional bacterial population characterized by high SSC (Fig. 1). Since this population with high SSC but comparable SYBR green derived fluorescence to HNA bacteria was not observed in the BC-free controls, it is likely that it consisted of bacteria associated with particles. The strong correlation between this bacterial FC population and $\mathrm{BC}$ concentration (Fig. 4A) supports the notion that these were BCassociated bacteria. Also, the similarity of the data on the fraction of particle-associated bacteria data obtained by FC and by epifluorescence microscopy supports this idea. The values of the side scatter in the FC cytograms for this type of particle increased during the course of the experiment (data not shown). Assuming that light scatter is proportional to the size of the particles (Koch et al. 1996), the data indicate that particles were increasing in size. Hence, a progressive aggregation of $\mathrm{BC}$ including colloids and bacterial cells into larger particles might have taken place. Different stages of association between bacteria and $\mathrm{BC}$ material, which range from small $\mathrm{BC}$ colloids attached to bacteria to bacteria completely entrapped in $\mathrm{BC}$ have been shown previously (Cattaneo et al. 2010), suggesting BC-driven aggregation and particle formation. This is supported by findings that $\mathrm{BC}$ reference material stimulated the formation of a specific class of organic aggregates, the transparent exopolymeric particles (Weinbauer et al. 2012, Mari et al. 2014). Also, in situ evidence suggests that soot deposition can increase coagulation and aggregation of organic matter (Mari et al. 2014).

Viral abundance per unit surface of BC decreased with $\mathrm{BC}$ particle size similarly to patterns previously observed in BC reference material (Cattaneo et al. 2010) and in other suspended material (Simon et al. 2002, Luef et al. 2007, Mari et al. 2007). The decreasing concentration of attached viruses with increasing particle size can be assigned to the fractal structure of BC particles (Slowik et al. 2007) which translates into increasing porosity with increasing particle size. Increasing porosity implies a higher content of pore water with potentially lower microbial and viral densities.

\section{Effect of BC on viral production and infection}

Free viral abundance was significantly lower in the $\mathrm{BC}$ treatments than in the controls (Table 2) and de- creased with BC concentrations (Fig. 4B). Viruses were found attached to $\mathrm{BC}$ particles as in experiments performed with water from the Mediterranean Sea (Cattaneo et al. 2010). VP and the fraction of infected cells were also significantly lower in the BC-amended treatments (Table 4, Fig. 6) except for the $\mathrm{BC}$-light treatment in $B C$-fix. In this treatment, the negative effects of $\mathrm{BC}$ on VP as experienced in the dark BC treatment (see discussion below) could have been compensated by an increased viral infection due to the stimulated bacterial production in BClight (see below) with the net outcome of no detectable effect of BC at a concentration of $200 \mu \mathrm{g} \mathrm{l^{-1 }}$.

Our data suggest that adsorption onto BC particles inactivated viruses and prevented infection of attached cells, or reduced infection by reducing the abundance of free viruses and thus encounter rates. Similarly, in a study with water from the Danube River, free viruses were scavenged on particles (Kernegger et al. 2009). Such a mechanism could have resulted in the increased BHP in the BC treatments as also observed for suspended material in the Danube River. Interestingly, particle quality was a determining factor for microbial attachment in these freshwater experiments, and significantly fewer viruses attached to mineral than to organic particles (Kernegger et al. 2009). In accordance, the addition of mineral particles, such as Saharan dust (Weinbauer et al. 2009, Pulido-Villena et al. 2014) or clay particles (Salter et al. 2011) to marine coastal waters led to a negligible sorption of viruses to particles and increased VP rates in contrast to the response of the microbial community to $\mathrm{BC}$ addition in the present study.

VP in solar radiation-exposed BC treatments was significantly stimulated with respect to the nonexposed BC (Table 4). This could be traced to the stimulation of bacterial production in BC-light treatments, since viral infection and production are related to bacterial activity and production (Wommack \& Colwell 2000). Also, viral adsorption or inactivation by $\mathrm{BC}$ could have been reduced due to UVexposure, thus allowing for higher infection rates.

\section{Effect of BC on bacterial production}

The addition of $\mathrm{BC}$ stimulated bacterial production in both experiments (Table 2). The positive correlation found between particle-associated bacteria and heterotrophic bacterial production as well as HNA bacteria, which are often the more active bacterial fraction (e.g. Gasol et al. 1999), suggests that 
attached bacteria were particularly active and contributed significantly to the measured bacterial production. Such an increased metabolic activity of attached bacteria has been found following the upregulation of enzyme activity upon colonization of organic aggregates (Riemann et al. 2000, Simon et al. 2002, Grossart et al. 2007). Historically, BC was assumed to be highly refractory (Schmidt \& Noack 2000), but an increasing body of literature shows abiotic (Decesari et al. 2002, Lehmann et al. 2005, Cheng et al. 2006, Stubbins et al. 2010, 2012) and biotic oxidation of BC in soils (Potter 1908, Shneour 1966, Cheng et al. 2006, 2008, Zimmerman 2010) and sediments (Middelburg et al. 1999). For example, oxidation of turbidite in the Madeira Abyssal Plain removed about $77 \%$ and $64 \%$ of organic and soot carbon, respectively, thus challenging the assumption that $\mathrm{BC}$ is biologically and chemically recalcitrant (Middelburg et al. 1999). However, since the quantification of BC was beyond the scope of this study, there is no direct evidence of $\mathrm{BC}$ decomposition or its use as a carbon source during our experiments. The addition of ammonium along with the BC material (Table 1) could have stimulated bacterial production, since the simultaneous addition of ammonium and organic carbon can stimulate bacterial production (Kirchman \& Rich 1997). However, the use of aged seawater and the finding that ammonium concentrations did not decrease with incubation time argues against such a mechanism. Another mechanism explaining increased bacterial activity could be the adsorption of DOC to BC particles, which could create hot spots of microbial activity similar to those observed in marine snow particles (Azam \& Malfatti 2007). It is well known that soot particles can interact with organic compounds (Rockne et al. 2000, Slowik et al. 2007) and redistribute them in the environment (Ahrens \& Morrisey 2005). There is additional evidence (Cattaneo et al. 2010, this study) that viruses, which are by definition part of the DOC pool, are rapidly adsorbed to BC. Overall, it is well known that organic compounds adsorb very efficiently to materials such as $\mathrm{BC}$, generally exceeding adsorption for typical amorphous organic matter by a factor of 10 to 100 (Cornelissen \& Gustafsson 2005, Cornelissen et al. 2005).

In both experiments, heterotrophic bacterial production was significantly higher after exposing BC to solar radiation. Photo-oxidation can induce chemical changes in the highly aromatic structure of BClike molecules (Stubbins et al. 2010), thus offering sites for degradation and increasing $\mathrm{BC}$ bioavailability. Stubbins et al. (2012) reported a 20 -fold decrease in marine dissolved $\mathrm{BC}$ concentration after exposure of North Atlantic Deep Water to simulated solar radiation confirming the high photo-lability of dissolved BC. Maki et al. (2001) found that the exposure of biodegraded crude oil to sunlight significantly decreased the aromatic fraction and that this material favored the growth of seawater microbes as compared to non-irradiated material (Maki et al. 2001). Our data suggest that light exposure of BC in surface waters can alter BHP. As aerosols are normally exposed to solar radiation during atmospheric transport with radiation levels potentially exceeding those observed in surface waters, our results also suggest that the distance from the $\mathrm{BC}$ source and its residence time in the atmosphere prior to the deposition on the ocean surface could be an important parameter modulating the effect of $\mathrm{BC}$ on the marine ecosystem.

\section{CONCLUSIONS}

Our study indicates that $\mathrm{BC}$ deposition in the ocean can stimulate heterotrophic bacterial production either by reducing the impact of viral lysis, by serving as a carbon source to bacteria, and/or by serving as hotspots due to organic matter adsorption. Our experiments also indicate that atmospheric transport of $\mathrm{BC}$, and the residence time in surface waters, will likely influence the effect on the microbial community, since exposure to solar radiation increased BC availability. Fossil-fuel and biomass burning will probably further increase in the future (Novakov et al. 2003), and the impact of $\mathrm{BC}$ on the functioning of the marine microbial food web is likely to become more important, particularly in coastal oceans. One of the potential consequences could be a shift in the metabolic balance of the planktonic ecosystem towards a more heterotrophic ocean.

Acknowledgements. We thank I. Lekunberri for help during the experiments. Previous reviewers contributed to improving the original manuscript with detailed comments and corrections. Financial support was provided by the European Union in the framework of the BASICS project (EVK3-CT2002-00078), by the Eur-Oceans Network of Excellence (Project Number WP4-SYSMS-1021), and a Spanish grant from the ministry of education (SB2010-0079) to A.M. J.M.G. is supported by grant STORM from the Spanish MICINN.

\section{LITERATURE CITED}

Ahrens MJ, Morrisey DJ (2005) Biological effects of unburned coal in the marine environment. Oceanogr Mar Biol Annu Rev 43:69-122 
Azam F, Malfatti F (2007) Microbial structuring of marine ecosystems. Nat Rev Microbiol 5:782-791

> Benner R, Strom M (1993) A critical evaluation of the analytical blank associated with DOC measurements by hightemperature catalytic oxidation. Mar Chem 41:153-160

Binder B (1999) Reconsidering the relationship between virally induced bacterial mortality and frequency of infected cells. Aquat Microb Ecol 18:207-215

$>$ Brussaard CPD (2004) Optimization of procedures for counting viruses by flow cytometry. Appl Environ Microbiol 70:1506-1513

> Cattaneo R, Rouviere C, Rassoulzadegan F, Weinbauer MG (2010) Association of marine viral and bacterial communities with reference black carbon particles under experimental conditions: an analysis with scanning electron, epifluorescence and confocal laser scanning microscopy. FEMS Microbiol Ecol 74:382-396

> Cheng CH, Lehmann J, Thies JE, Burton SD, Engelhard MH (2006) Oxidation of black carbon by biotic and abiotic processes. Org Geochem 37:1477-1488

> Cheng CH, Lehmann J, Engelhard MH (2008) Natural oxidation of black carbon in soils: changes in molecular form and surface charge along a climosequence. Geochim Cosmochim Acta 72:1598-1610

> Cornelissen G, Gustafsson O (2005) Importance of unburned coal carbon, black carbon, and amorphous organic carbon to phenanthrene sorption in sediments. Environ Sci Technol 39:764-769

Cornelissen G, Gustafsson O, Bucheli TD, Jonker MTO, Koelmans AA, van Noort PCM (2005) Extensive sorption of organic compounds to black carbon, coal, and kerogen in sediments and soils: mechanisms and consequences for distribution, bioaccumulation, and biodegradation. Environ Sci Technol 39:6881-6895

> Decesari S, Facchini MC, Matta E, Mircea M, Fuzzi S, Chughtai AR, Smith DM (2002) Water soluble organic compounds formed by oxidation of soot. Atmos Environ 36:1827-1832

del Giorgio PA, Prairie YT, Bird DF (1997) Coupling between rates of bacterial production and the abundance of metabolically active bacteria in lakes, enumerated using CTC reduction and flow cytometry. Microb Ecol 34:144-154

> Dickens AF, Gelinas Y, Masiello CA, Wakeham S, Hedges JI (2004) Reburial of fossil organic carbon in marine sediments. Nature 427:336-339

> Dittmar T, Koch BP (2006) Thermogenic organic matter dissolved in the abyssal ocean. Mar Chem 102:208-217

Dittmar T, Paeng J (2009) A heat-induced molecular signature in marine dissolved organic matter. Nat Geosci 2: 175-179

Dittmar T, Paeng J, Gihring TM, Suryaputra IGNA, Huettel M (2012) Discharge of dissolved black carbon from a fire-affected intertidal system. Limnol Oceanogr 57: 1171-1181

> Elmquist M, Semiletov I, Guo L, Gustafsson Ö (2008) PanArctic patterns in black carbon sources and fluvial discharges deduced from radiocarbon and PAH source apportionment markers in estuarine surface sediments. Global Biogeochem Cycles 22, GB2018, doi:10.1029/ 2007GB002994

Falcioni T, Papa S, Gasol JM (2008) Evaluating the flowcytometric nucleic acid double-staining protocol in realistic situations of planktonic bacterial death. Appl Environ Microbiol 74:1767-1779
Flores-Cervantes DX, Plata DL, MacFarlane JK, Reddy CM, Gschwend PM (2009) Black carbon in marine particulate organic carbon: inputs and cycling of highly recalcitrant organic carbon in the Gulf of Maine. Mar Chem 113: 172-181

Fuhrman JA (1999) Marine viruses and their biogeochemical and ecological effects. Nature 399:541-548

- Gasol JM, Arístegui J (2007) Cytometric evidence reconciling the toxicity and usefulness of CTC as a marker of bacterial activity. Aquat Microb Ecol 46:71-83

Gasol MJ, del Giorgio PA (2000) Using flow cytometry for counting natural planktonic bacteria and understanding the structure of planktonic bacterial communities. Sci Mar 64:197-224

> Gasol JM, Zweifel UL, Peters F, Fuhrman JA, Hagstrom A (1999) Significance of size and nucleic acid content heterogeneity as measured by flow cytometry in natural planktonic bacteria. Appl Environ Microbiol 65: 4475-4483

Goldberg ED (1985) Black carbon in the environment: properties and distribution. J. Wiley, New York, NY

Gordon LI, Jennings JCJ, Ross AA, Krest JM (1993) A suggested protocol for continuous flow automated analysis of seawater nutrients (phosphate, nitrate, nitrite and silic acid) in the WOCE hydrographic program and the Joint Global Ocean Fluxes Study. WOCE Operations Manual. WHP Office Report WHPO 91-1. WOCE Report No. 68/91. Revision 1. Woods Hole, MA

Gregori G, Citterio S, Ghiani A, Labra M, Sgorbati S, Brown S, Denis M (2001) Resolution of viable and membranecompromised bacteria in freshwater and marine waters based on analytical flow cytometry and nucleic acid double staining. Appl Environ Microbiol 67:4662-4670

Grossart HP, Tang KW, Kiorboe T, Ploug H (2007) Comparison of cell-specific activity between free-living and attached bacteria using isolates and natural assemblages. FEMS Microbiol Lett 266:194-200

> Gustafsson Ö, Haghseta F, Chan C, MacFarlane J, Gschwend PM (1997) Quantification of the dilute sedimentary soot phase: implications for PAH speciation and bioavailability. Environ Sci Technol 31:203-209

Hadley OL, Ramanathan V, Carmichael GR, Tang Y, Corrigan CE, Roberts GC, Mauger GS (2007) Trans-Pacific transport of black carbon and fine aerosols $(\mathrm{D}<2.5 \mu \mathrm{m})$ into North America. J Geophys Res 112, D05309, doi: 10.1029/2006JD007632

Helder W, De Vries RTP (1979) Automatic phenol-hypochlorite method for the determination of ammonia in sea and brackish waters. Neth J Sea Res 13:154-160

Jensen KA (2006) Nano-size heavy metal particles in authentic air and diesel emission particles. Geophys Res Abstracts 8:09658

> Jurado E, Dachs J, Duarte CM, Simó R (2008) Atmospheric deposition of organic and black carbon to the global oceans. Atmos Environ 42:7931-7939

Kernegger L, Zweimüller I, Peduzzi P (2009) Effects of suspended matter quality and virus abundance on microbial parameters: experimental evidence from a large European river. Aquat Microb Ecol 57:161-173

> Kim S, Kaplan LA, Benner R, Hatcher PG (2004) Hydrogendeficient molecules in natural riverine water samples evidence for the existence of black carbon in DOM. Mar Chem 92:225-234

Kirchman DL, Rich JH (1997) Regulation of bacterial growth rates by dissolved organic carbon and temperature in the 
equatorial Pacific Ocean. Microb Ecol 33:11-20

Koch AL, Robertson BR, Button DK (1996) Deduction of the cell volume and mass from forward scatter intensity of bacteria analyzed by flow cytometry. J Microbiol Methods 27:49-61

Koelmans AA, Jonker MTO, Cornelissen G, Bucheli TD, Van Noort PCM, Gustafsson O (2006) Black carbon: the reverse of its dark side. Chemosphere 63:365-377

Lack D, Lerner B, Granier C, Baynard T and others (2008) Light absorbing carbon emissions from commercial shipping. Geophys Res Lett 35, L13815, doi:10.1029/ 2008GL033906

> Lee S, Fuhrman JE (1987) Relationship between biovolume and biomass of naturally derived marine bacterioplankton. Appl Environ Microbiol 53:1298-1303

> Lehmann J, Liang B, Solomon D, Lerotic M and others (2005) Near-edge X-ray absorption fine structure (NEXAFS) spectroscopy for mapping nano-scale distribution of organic carbon forms in soil: application to black carbon particles. Global Biogeochem Cycles 19, GB1013, doi: 10.1029/2004GB002435

> Luef B, Aspetsberger F, Hein T, Huber F, Peduzzi P (2007) Impact of hydrology on free-living and particle-associated microorganisms in a river floodplain system (Danube, Austria). Freshw Biol 52:1043-1057

Luef B, Neu TR, Peduzzi P (2009) Imaging and quantifying virus fluorescence signals on aquatic aggregates: a new method and its implication for aquatic microbial ecology. FEMS Microbiol Ecol 68:372-380

Maki H, Sasaki T, Harayama S (2001) Photo-oxidation of biodegraded crude oil and toxicity of the photo-oxidized products. Chemosphere 44:1145-1151

> Mannino A, Harvey HR (2004) Black carbon in estuarine and coastal ocean dissolved organic matter. Limnol Oceanogr 49:735-740

- Mari X, Kerros ME, Weinbauer MG (2007) Virus attachment to transparent exopolymeric particles along trophic gradients in the southwestern lagoon of New Caledonia. Appl Environ Microbiol 73:5245-5252

Mari X, Lefèvre J, Torréton JP, Bettarel Y and others (2014) Effects of soot deposition on particle dynamics and microbial processes in marine surface waters. Global Biogeochem Cycles 28:662-678

Masiello CA (2004) New directions in black carbon organic geochemistry. Mar Chem 92:201-213

> Masiello CA, Druffel ERM (1998) Black carbon in deep-sea sediments. Science 280:1911-1913

> Middelburg JJ, Nieuwenhuize J, van Breugel P (1999) Black carbon in marine sediments. Mar Chem 65:245-252

> Mitra S, Bianchi TS, McKee BA, Sutula M (2002) Black carbon from the Mississippi River: quantities, sources, and potential implications for the global carbon cycle. Environ Sci Technol 36:2296-2302

Noble RT, Fuhrman JA (1997) Virus decay and its causes in coastal waters. Appl Environ Microbiol 63:77-83

> Noble RT, Fuhrman JA (1998) Use of SYBR Green I for rapid epifluorescence counts of marine viruses and bacteria. Aquat Microb Ecol 14:113-118

Novakov T, Ramanathan V, Hansen JE, Kirchstetter TW, Sato M, Sinton JE, Sathaye JA (2003) Large historical changes of fossil-fuel black carbon aerosols. Geophys Res Lett 30,1324, doi:10.1029/2002GL016345

Parada V, Herndl GJ, Weinbauer MG (2006) Viral burst size of heterotrophic prokaryotes in aquatic systems. J Mar Biol Assoc UK 86:613-621
Paul JH, Weinbauer MG (2010) Detection of lysogeny in marine environments. In: Suttle C, Wilhelm SW, Weinbauer MG (eds) Manual of aquatic viral ecology. ASLO, p 30-33

> Pausz C, Herndl GJ (2002) Role of nitrogen versus phosphorus availability on the effect of UV radiation on bacterioplankton and their recovery from previous UV stress. Aquat Microb Ecol 29:89-95

> Peduzzi P, Weinbauer MG (1993) Effect of concentrating the virus-rich 2-200-nm size fraction of seawater on the formation of algal flocs (marine snow). Limnol Oceanogr 38: 1562-1565

Potter MC (1908) Bacteria as agents in the oxidation of amorphous carbon. Proc R Soc Lond 80:239-259

> Pulido-Villena E, Baudoux AC, Obernosterer I, Landa M and others (2014) Microbial food web dynamics in response to a Saharan dust event: results from a mesocosm study in the oligotrophic Mediterranean Sea. Biogeosciences 11:5607-5619

> Ramanathan V, Carmichael G (2008) Global and regional climate changes due to black carbon. Nat Geosci 1: 221-227

> Riemann L, Grossart HP (2008) Elevated lytic phage production as a consequence of particle colonization by a marine flavobacterium (Cellulophaga sp.). Microb Ecol 56: 505-512

> Riemann B, Russell TB, Jørgensen NOG (1990) Incorporation of thymidine, adenine and leucine into natural bacterial assemblages. Mar Ecol Prog Ser 65:87-94

Riemann L, Steward GF, Azam F (2000) Dynamics of bacterial community composition and activity during a mesocosm diatom bloom. Appl Environ Microbiol 66:578-587

> Rockne KJ, Taghon GL, Kosson DS (2000) Pore structure of soot deposits from several combustion sources. Chemosphere 41:1125-1135

Salter I, Böttjer D, Christaki U (2011) The effect of inorganic particle concentration on bacteria-virus-nanoflagellate dynamics. Environ Microbiol 13:2768-2777

Schmidt MWI, Noack AG (2000) Black carbon in soils and sediments: analysis, distribution, implications, and current challenges. Global Biogeochem Cycles 14:777-793

Sheik AR, Brussaard CPD, Lavik G, Lam P and others (2014) Responses of the coastal bacterial community to viral infection of the algae Phaeocystis globosa. ISME J 8: 212-225

Sherr EB, Sherr BF, Sigmon CT (1999) Activity of marine bacteria under incubated and in situ conditions. Aquat Microb Ecol 20:213-223

Shneour EA (1966) Oxidation of graphitic carbon in certain soils. Science 151:991-992

Sieracki ME, Cucci TL, Nicinski J (1999) Flow cytometric analysis of 5-cyano-2,3-ditolyl tetrazolium chloride activity of marine bacterioplankton in dilution cultures. Appl Environ Microbiol 65:2409-2417

Simon M, Azam F (1989) Protein content and protein synthesis rates of planktonic marine bacteria. Mar Ecol Prog Ser 51:201-213

Simon M, Grossart HP, Schweitzer B, Ploug H (2002) Microbial ecology of organic aggregates in aquatic ecosystems. Aquat Microb Ecol 28:175-211

> Slowik JG, Cross ES, Han JH, Kolucki J and others (2007) Measurements of morphology changes of fractal soot particles using coating and denuding experiments: implications for optical absorption and atmospheric lifetime. Aerosol Sci Technol 41:734-750 
Stubbins A, Spencer RGM, Chen H, Hatcher PG and others (2010) Illuminated darkness: molecular signatures of Congo River dissolved organic matter and its photochemical alteration as revealed by ultrahigh precision mass spectrometry. Limnol Oceanogr 55:1467-1477

Stubbins A, Niggemann J, Dittmar T (2012) Photo-lability of deep ocean dissolved black carbon. Biogeosciences 9: 1661-1670

Suttle CA (2007) Marine viruses - major players in the global ecosystem. Nat Rev Microbiol 5:801-812

Suttle CA, Chen F (1992) Mechanisms and rates of decay of marine viruses in seawater. Appl Environ Microbiol 58: 3721-3729

Weinbauer MG, Winter C, Hoefle MG (2002) Reconsidering transmission electron microscopy based estimates of viral infection of bacterioplankton using conversion factors derived from natural communities. Aquat Microb Ecol 27:103-110

Weinbauer MG, Bettarel Y, Cattaneo R, Luef B and others (2009) Viral ecology of organic and inorganic particles in aquatic systems: avenues for further research. Aquat

Editorial responsibility: Hans-Georg Hoppe, Kiel, Germany
Microb Ecol 57:321-341

Weinbauer MG, Rowe JM, Wilhelm SW (2010) Determining rates of virus production in aquatic systems by the virus reduction approach. In: Suttle C, Wilhelm SW, Weinbauer MG (eds) Manual of aquatic viral ecology. ASLO, p 1-8

Weinbauer MG, Cattaneo R, Malits A, Motegi C and others (2012) Black carbon and microorganisms in aquatic systems. In: Daniels JA (ed) Advances in environmental research, Vol 25. Nova Science Publishers, New York, NY, p 1-37

Wilhelm SW, Suttle CA (1999) Virus and nutrient cycles in the sea. BioScience 49:781-787

Wommack KE, Colwell RR (2000) Virioplankton: viruses in aquatic ecosystems. Microbiol Mol Biol Rev 64:69-114

Zimmerman AR (2010) Abiotic and microbial oxidation of laboratory-produced black carbon (biochar). Environ Sci Technol 44:1295-1301

Ziolkowski LA, Druffel ERM (2010) Aged black carbon identified in marine dissolved organic carbon. Geophys Res Lett 37, L16601, doi:10.1029/2010GL043963

Submitted: June 12, 2014; Accepted: January 29, 2015 Proofs received from author(s): 